\title{
Effect of burning on seed production of bluebunch wheat- grass, Idaho fescue, and Columbia needlegrass
}

\author{
BOB D. PATTON, M. HIRONAKA, AND STEPHEN C. BUNTING
}

\section{Abstract}

A study was conducted in 1984 to determine the effect of fall prescribed burning on seed production of bluebunch wheatgrass (Agropyron spicatum), Idaho fescue (Festuca idahoensis), and Columbia needlegrass (Stipa columbiana) in the sagebrush (Artemisia spp.)/grassland region. Plots were located on 7 burns of ages 1 to 5 years, with plots in adjacent unburned areas serving as controls. Seed production (seeds per plant) of bluebunch wheatgrass was greater on 2 of four 1-year-old burns and on one 3-yearold burn than on unburned comparison areas. Idaho fescue seed production was greater on a 5-year old bum than on the control plot, but not statistically different from the controls on 1- or 3-year-old burns. Columbia needlegrass seed production was markedly greater on a 2-year-old burn than on adjacent unburned areas. The percentage of filled florets and the number of seeds per inflorescence tended to be greater on burned plots for all 3 species. Bluebunch wheatgrass showed a variable response in the number of inflorescences produced per plant 1 year after burning, but there were significantly $(P \leq 0.05)$ more inflorescences per plant on the 3-year-old burn than the control. Idaho fescue plants produced fewer inflorescences on both 1-year-old burns than on the control plots, but more on the 5-year-old burn than on the control. Columbia needlegrass plants produced more inflorescences on the burn than on the control.

Key Words: fire, Agropyron spicatum, Festuca idahoensis, Stipa columbiana

Fire is often prescribed in sagebrush/grass communities of the Intermountain West to reduce sagebrush cover and release perennial bunchgrasses from competition for light and moisture. Fire improves the range for cattle grazing by increasing forage yields and enhancing cattle movement (Wright et al. 1979).

Current practice is to rest a pasture for 1 growing season before burning to allow the build-up of fine fuels, and to rest the pasture for 2 growing seasons after burning to provide perennial grasses time to recover vigor and to promote seedling establishment (Wright et al. 1979). Bunchgrasses reproduce through seed, so good seed production is essential to maintain healthy, vigorous grass stands. Forage yields are often increased (Blaisdell 1953, Harniss and Murray 1973, Uresk et al. 1976, Wright et al. 1979) but the effect of burning on seed production of bunchgrasses has not been studied.

Our purpose in this study is to examine the effect of prescribed burning on seed production of bluebunch wheatgrass, Idaho fescue, and Columbia needlegrass on basin big sagebrush (Artemisia tridentata spp. tridentata)/Idaho fescue and mountain big sagebrush ( $A$. tridentata spp. vaseyana)/Idaho fescue habitat types (Hironaka et al. 1983).

\section{Study Areas}

Seven study sites were selected from fall prescribed burns in the Boise, Idaho; Shoshone, Idaho; and Vale, Oregon, districts of the

\footnotetext{
Authors are graduate student, professor, and associate professor, Department of Range Resources, University of Idaho, Moscow 83843. The senior author's current address is Central Grasslands, Research Station, Streeter, North Dakota 58483.

Research was funded in part by a fellowship from the Stillinger Foundation, University of Idaho.

Manuscript accepted 8 December 1987.
}

Bureau of Land Management, USDI. The sites ranged in elevation from 1,372 to $1,743 \mathrm{~m}$, aspects were generally northern, and slopes were from 1 to $34 \%$. The average annual precipitation for the sites ranged from 30 to $41 \mathrm{~cm}$. Four 1-year-old burns and one 3-year-old burn were selected for study of bluebunch wheatgrass. Two 1-yearold, one 3-year-old, and one 5-year-old burns were chosen for study of Idaho fescue. One 2-year-old burn was selected for Columbia needlegrass.

\section{Methods}

On each site, macroplots were delineated on the burn and on a comparable, nearby area that had not been burned. In most cases, the macroplots were 50 by $50 \mathrm{~m}$, but in a few instances they were smaller to maintain homogeneity of site and vegetation. The control and treatment plots were paired as nearly as possible with respect to elevation, aspect, slope, soil, and understory vegetation, including density of the species under study.

Five 25-m transects were randomly located on each site and 20 points were randomly located along each transect. The bunchgrass plant nearest to each point was selected and marked. Inflorescences were collected when the seed ripened. When this method did not result in sampling at least 60 plants with inflorescences, it was felt that the sample size was inadequate. In this case, inflorescences were also collected from all plants in 1 by $25-\mathrm{m}$ belt transects. The number of transects was increased until at least 400 inflorescences from at least 100 plants had been collected. Since the plants within a belt transect were not randcmly selected, the average of the various characteristics of the plants within the transect had to be used as the sample unit rather than the individual plants. This resulted in a smaller sample size but less variability between samples.

In the laboratory, the inflorescences were counted, the florets removed from the inflorescences, and filled and empty florets separated and counted on a light table. The mean numbers of inflorescences per plant, seeds per plant, seeds per inflorescence, and percentage of filled florets were calculated for each plot. Data were analyzed by standard $t$-test for the means.

\section{Results and Discussion}

\section{Bluebunch Wheatgrass}

An increase in seed production by a plant may be due to a greater number of inflorescences and/or a higher number of seeds per inflorescence (i.e., more florets or a greater percentage of filled florets). Each of these factors was examined in this study.

Seed production per bluebunch wheatgrass was greater on the burn than on the control for 3 of the 5 sites examined (Table 1). There was no difference in mean seed production per plant between the burn and control for the other 2 sites. The greatest difference in seed production was between the 3-year-old burn and its control (200 vs. 20 seeds/plant). The high productivity of the plants on this burn may be due to the long recovery time since burning, the timing of the burn in relation to soil moisture availability, or greater productivity of the site. The control plot for the 3-year-old burn produced almost twice as many seeds per plant as the control for the next most productive site. In any case, there seems to be evidence that the effect of burning resulted in greater seed production. 
Table 1. Mean number of seeds and Inflorescence/bluebunch wheatgrass plant by sample site.

\begin{tabular}{|c|c|c|c|c|c|}
\hline Habitat type & $\begin{array}{l}\text { Age of burn } \\
\text { (years) }\end{array}$ & Treatment & Seeds/plant & Inflor./plant & Sample sizel \\
\hline $\begin{array}{l}\text { basin big sagebrush/ } \\
\text { Idaho fescue }\end{array}$ & 1 & $\begin{array}{l}\text { burn } \\
\text { control }\end{array}$ & $\begin{array}{l}0.5 \pm 0.52 \\
0.6 \pm 0.4\end{array}$ & $\begin{array}{l}0.4 \pm 0.3 \\
1.3 \pm 0.6 *\end{array}$ & $\begin{array}{l}100 \\
100\end{array}$ \\
\hline $\begin{array}{l}\text { basin big sagebrush/ } \\
\text { Idaho fescue }\end{array}$ & 1 & $\begin{array}{l}\text { burn } \\
\text { control }\end{array}$ & $\begin{aligned} 30 & \pm 10 \\
6 & \pm 3^{* * * *}\end{aligned}$ & $\begin{array}{r}10 \pm 2 \\
8 \pm 3\end{array}$ & $\begin{array}{l}100 \\
100\end{array}$ \\
\hline $\begin{array}{l}\text { mountain big sagebrush/ } \\
\text { Idaho fescue }\end{array}$ & 1 & $\begin{array}{l}\text { burn } \\
\text { control }\end{array}$ & $\begin{array}{c}20 \pm 10 \\
2 \pm 1\end{array}$ & $\begin{array}{l}3.2 \pm 1.7 \\
1.3 \pm 0.6^{*}\end{array}$ & $\begin{array}{l}91 \\
97\end{array}$ \\
\hline $\begin{array}{l}\text { mountain big sagebrush/ } \\
\text { Idaho fescue }\end{array}$ & 1 & $\begin{array}{l}\text { burn } \\
\text { control }\end{array}$ & $\begin{array}{l}20 \pm 10 \\
10 \pm 10\end{array}$ & $\begin{array}{l}3 \pm 2 \\
3 \pm 1\end{array}$ & $\begin{array}{l}100 \\
100\end{array}$ \\
\hline $\begin{array}{l}\text { mountain big sagebrush/ } \\
\text { Idaho fescue }\end{array}$ & 3 & $\begin{array}{l}\text { burn } \\
\text { control }\end{array}$ & $\begin{aligned} 200 & \pm 100 \\
20 & \pm 20^{* * *}\end{aligned}$ & $\begin{array}{l}45 \pm 11 \\
20 \pm 10^{* * *}\end{array}$ & $\begin{array}{l}30 \\
30\end{array}$ \\
\hline
\end{tabular}

${ }^{1} \mathrm{n}=$ number of plants.

2 Means \pm confidence limits $(P \leq 0.10)$.

$*+*, *$ Significant at the $0.10,0.05$, and 0.01 levels, respectively.

Table 2. Mean number of florets/inflorescence, pereentage of flled forets, and seeds/inflorescence on bluebunch wheatgrass plants by sample site.

\begin{tabular}{|c|c|c|c|c|c|c|}
\hline Habitat type & $\begin{array}{c}\text { Age of burn } \\
\text { (years) }\end{array}$ & Treatment & $\begin{array}{l}\text { Florets/ } \\
\text { inflorescencel }^{1}\end{array}$ & $\begin{array}{l}\text { Filled florets } \\
(\%)\end{array}$ & $\begin{array}{l}\text { Seeds/ } \\
\text { inflorescence }\end{array}$ & $\begin{array}{c}\text { Sample } \\
\text { size }^{2}\end{array}$ \\
\hline $\begin{array}{l}\text { basin big sagebrush/ } \\
\text { Idaho fescue }\end{array}$ & 1 & $\begin{array}{l}\text { burn } \\
\text { control }\end{array}$ & $\begin{array}{l}31 \\
25\end{array}$ & $\begin{array}{l}1.3 \pm 0.7^{3} \\
0.8 \pm 0.5\end{array}$ & $\begin{array}{l}04 . \pm 0.2 \\
0.2 \pm 0.2\end{array}$ & $\begin{array}{l}9 \mathrm{~T}^{4} \\
7 \mathrm{~T}\end{array}$ \\
\hline $\begin{array}{l}\text { basin big sagebrush/ } \\
\text { Idaho fescue }\end{array}$ & 1 & $\begin{array}{l}\text { burn } \\
\text { control }\end{array}$ & $\begin{array}{l}22 \\
22\end{array}$ & $\begin{aligned} 13 & \pm 2 \\
4 & \pm 1 * *\end{aligned}$ & $\begin{array}{c}3 \pm 0.6 \\
0.8 \pm 0.3^{* * * *}\end{array}$ & $\begin{array}{l}81 \\
53\end{array}$ \\
\hline $\begin{array}{l}\text { mountain big sagebrush/ } \\
\text { Idaho fescue }\end{array}$ & 1 & $\begin{array}{l}\text { burn } \\
\text { control }\end{array}$ & $\begin{array}{l}50 \\
25\end{array}$ & $\begin{array}{l}10 \pm 4 \\
5 \pm 2^{* *}\end{array}$ & $\begin{array}{l}5 \pm 2 \\
1.3 \pm 0.4^{* * *}\end{array}$ & $\begin{array}{l}27 \\
25\end{array}$ \\
\hline $\begin{array}{l}\text { mountain big sagebrush/ } \\
\text { Idaho fescue }\end{array}$ & 1 & $\begin{array}{l}\text { burn } \\
\text { control }\end{array}$ & $\begin{array}{l}41 \\
25\end{array}$ & $\begin{array}{l}16 \pm 3 \\
13 \pm 2\end{array}$ & $\begin{array}{l}7 \pm 2 \\
3.3 \pm 0.8 * * *\end{array}$ & $\begin{array}{l}41 \\
38\end{array}$ \\
\hline $\begin{array}{l}\text { mountain big sagebrush/ } \\
\text { Idaho fescue }\end{array}$ & 3 & $\begin{array}{l}\text { burn } \\
\text { control }\end{array}$ & $\begin{array}{l}18 \\
21\end{array}$ & $\begin{aligned} 20 & \pm 5 \\
6 & \pm 3^{* * *}\end{aligned}$ & $\begin{array}{l}3.7 \pm 0.9 \\
1.3 \pm 0.7 * * *\end{array}$ & $\begin{array}{l}29 \\
26\end{array}$ \\
\hline
\end{tabular}

1 Florets/inflorescence was derived by dividing seeds/inflorescence by percent filled florets.

${ }^{2} \mathrm{n}=$ number of plants.

3Mean $t$ confidence limits $(P \leq 0.10)$.

$4 T=$ number of belt transects $(1 \times 25 \mathrm{~m}$; due to scarcity of plants, the mean of all plants in each transect was used to reduce the sample variance).

$*, \cdots+, * *+$ Significant at the $0.10,0.05$, and 0.01 levels respectively.

Table 3. Mean number of seeds and inflorescences/ldaho feacue plant by sample site.

\begin{tabular}{|c|c|c|c|c|c|}
\hline Habitat type & $\begin{array}{l}\text { Age of burn } \\
\text { (years) }\end{array}$ & Treatment & Seeds/plant & Inflor./plant & Sample size \\
\hline $\begin{array}{l}\text { basin big sagebrush/ } \\
\text { Idaho fescue }\end{array}$ & 1 & $\begin{array}{l}\text { burn } \\
\text { control }\end{array}$ & $\begin{array}{l}1 \pm 12 \\
3 \pm 2\end{array}$ & $\begin{array}{l}0.3 \pm 0.2 \\
1.3 \pm 0.5^{* * *}\end{array}$ & $\begin{array}{l}100 \\
100\end{array}$ \\
\hline $\begin{array}{l}\text { mountain big sagebrush/ } \\
\text { Idaho fescue }\end{array}$ & 1 & $\begin{array}{l}\text { burn } \\
\text { control }\end{array}$ & $\begin{array}{l}1 \pm 1 \\
1 \pm 1\end{array}$ & $\begin{array}{l}0.6 \pm 0.4 \\
1.5 \pm 0.4^{* *}\end{array}$ & $\begin{array}{l}100 \\
100\end{array}$ \\
\hline $\begin{array}{l}\text { mountain big sagebrush/ } \\
\text { Idaho fescue }\end{array}$ & 3 & $\begin{array}{l}\text { burn } \\
\text { control }\end{array}$ & $\begin{array}{l}9 \pm 8 \\
3 \pm 1\end{array}$ & $\begin{array}{l}8 \pm 2 \\
6 \pm 2\end{array}$ & $\begin{array}{l}100 \\
100\end{array}$ \\
\hline $\begin{array}{l}\text { mountain big sagebrush/ } \\
\text { Idaho fescue }\end{array}$ & 5 & $\begin{array}{l}\text { burn } \\
\text { control }\end{array}$ & $\begin{aligned} 40 & \pm 10 \\
5 & \pm 2^{* * *}\end{aligned}$ & $\begin{array}{l}12 \pm 3 \\
4 \pm 1^{* * *}\end{array}$ & $\begin{array}{l}100 \\
100\end{array}$ \\
\hline
\end{tabular}

$I_{n}=$ number of plants

2 Mean \pm confidence limits $(P \leq 0.10)$.

$* * *, * *$ Significant at the $0.10,0.05$, and 0.01 levels, respectively.

Several studies have shown an increase in the number of inflorescences per plant following burning (Blaisdell 1953, Clifton $\left.1981^{1}\right)$. In this study, the 3-year-old burn and one 1-year-old burn produced more inflorescences than their control plots $(P \leq 0.10)$, but one 1-year-old burn produced fewer inflorescences per plant than its control $(P \leq 0.05)$ (Table 1).

Plants on the burns produced more florets per inflorescence on only $\mathbf{3}$ of the 5 sites (Table 2). The percentage of filled florets was

Clifton, N.A. 1981. Responses to prescribed fire in a Wyoming big sagebrush/ bluebunch wheatgrass habitat type. M.S. Thesis, Univ. of Idaho, Moscow. significantly $(P \leq 0.05)$ greater for the plants on the burn on 3 of the 5 sites and not significantly $(P \leq 0.10)$ different on the other 2 sites (Table 2). Through combinations of more florets per inflorescence and greater percentages of filled florets, seed production per inflorescence was significantly $(P \leq 0.01)$ greater on the burns on 4 of the 5 sites (Table 2).

\section{Idaho Fescue}

Seed production per Idaho fescue plant was greater on the 5 -year-old burn than on its control (Table 3). There was no difference in seed production between the burn and its control on the 
Table 4. Mean number of florets/inflorescence, percentage of filled florets, and seeds/inflorescence on Idaho fescue plants by sample site.

\begin{tabular}{|c|c|c|c|c|c|c|}
\hline Habitat type & $\begin{array}{c}\text { Age of burn } \\
\text { (years) }\end{array}$ & Treatment & $\begin{array}{l}\text { Florets/ } \\
\text { inflorescencel }\end{array}$ & $\begin{array}{l}\text { Filled florets } \\
(\%)\end{array}$ & $\begin{array}{l}\text { Seeds/ } \\
\text { inflorescence }\end{array}$ & $\begin{array}{c}\text { Sample } \\
\text { size }^{2}\end{array}$ \\
\hline $\begin{array}{l}\text { basin big sagebrush/ } \\
\text { Idaho fescue }\end{array}$ & 1 & $\begin{array}{l}\text { burn } \\
\text { control }\end{array}$ & $\begin{array}{l}35 \\
30\end{array}$ & $\begin{array}{l}9 \pm 6^{3} \\
5 \pm 3\end{array}$ & $\begin{array}{c}3 \pm 3 \\
1.6 \pm 0.8\end{array}$ & $\begin{array}{l}12 \\
32\end{array}$ \\
\hline $\begin{array}{l}\text { mountain big sagebrush/ } \\
\text { Idaho fescue }\end{array}$ & 1 & $\begin{array}{l}\text { burn } \\
\text { control }\end{array}$ & $\overline{44}$ & $\overline{2 \pm 1}$ & $\begin{array}{r}4.6 \pm 2.0 \\
1 \pm 1^{* *}\end{array}$ & $\begin{array}{c}5 \mathrm{~T}^{3} \\
53\end{array}$ \\
\hline $\begin{array}{l}\text { mountain big sagebrush/ } \\
\text { Idaho fescue }\end{array}$ & 3 & $\begin{array}{l}\text { burn } \\
\text { control }\end{array}$ & $\begin{array}{l}32 \\
35\end{array}$ & $\begin{array}{l}3 \pm 1 \\
2 \pm 1^{*}\end{array}$ & $\begin{array}{l}1.0 \pm 0.4 \\
0.6 \pm 0.3\end{array}$ & $\begin{array}{l}72 \\
78\end{array}$ \\
\hline $\begin{array}{l}\text { mountain big sagebrush/ } \\
\text { Idaho fescue }\end{array}$ & 5 & $\begin{array}{l}\text { burn } \\
\text { control }\end{array}$ & $\begin{array}{l}28 \\
32\end{array}$ & $\begin{aligned} 12 & \pm 2 \\
5 & \pm 2 * * *\end{aligned}$ & $\begin{array}{l}3.5 \pm 0.7 \\
1.6 \pm 0.7^{* *}\end{array}$ & $\begin{array}{l}82 \\
64\end{array}$ \\
\hline
\end{tabular}

1Florets/inflorescence was derived by dividing seeds/inflorescence by percent filled seeds.

$2 n=$ number of plants

${ }^{3}$ Mean \pm confidence limits $(P \leq 0.10)$.

NNot sampled.

'T = number of belt transects ( $1 \times 25 \mathrm{~m}$; due to scarcity of plants, the mean of all plants in each belt was used to reduce sample variance).

$*, * * * * *$ Significant at the $0.10,0.05$, and 0.01 kevels, respectively.

other 3 sites. There may have been an increase in seed production with time subsequent to burning, but the results are not conclusive.

The number of inflorescences per Idaho fescue plant were less on both 1-year-old burns than on their controls (Table 3). This demonstrates the sensitivity of Idaho fescue plants to burning, which has been reported by Blaisdell (1953) and Countryman and Cornelius (1957). There was no difference in the number of inflorescences per plant between the 3-year-old burn and its control, and the plants on the 5-year-old burn produced more inflorescences than the plants on the control. The Idaho fescue plants appear to have regained their vigor by the third year following burning, and improved in vigor by the fifth year.

On Idaho fescue plants, the number of florets per inflorescence was similar for burned and control plots, but the percentage of filled florets was greater for plants on the 3-year-old and 5-year-old burns (Table 4). The number of seeds per inflorescence was greater on one 1-year-old burn and the 5-year-old burn than on the control plots (Table 4).

\section{Columbia Needlegrass}

Data for Columbia needlegrass were available for only 1 site which had been burned 2 years before sampling. On this site, Columbia needlegrass seed production was greater on the burn (500 vs. 16 seeds/plant). Plants on the burn produced more inflorescences (14 vs. 2 inflorescences/plant and more seeds per inflorescence ( 30 vs. 10 seeds/inflorescence). Greater seed production per inflorescence was due to a greater number of florets per inflorescence ( 55 vs. 22 florets/inflorescence) while the percentage of filled florets ( $50 \%$ on the burn vs $45 \%$ on the control) did not differ significantly $(P \leq 0.10)$.

The effect of burning seemed to stimulate seed production in each of these species, although for Idaho fescue this effect may not be significant until 5 years after burning. The percentage of filled florets and the number of seeds produced per inflorescence tended to be greater on the burned plots than on the controls, and this difference seemed to increase with time since burning.

\section{Literature Cited}

Blaisdell, J.P. 1953. Ecological effects of planned burning of sagebrushgrass range on the Upper Snake River Plains. USDA Tech. Bull. 1075.

Countryman, C.M., and D.R. Cornelius. 1957. Some effects of fire on a perennial range type. J. Range Manage. 10:39-41.

Harniss, R.O., and R.B. Murray. 1973. 30 years of vegetal change following burning of sagebrush-grass range. J. Range Manage. 26:322-325.

Hironaka, M., M.A. Fosberg, and A.H. Winward. 1983. Sagebrush-grass habitat types of southern Idaho. Bull. 35. Forest, Wildlife and Range Exp. Sta., Univ. of Idaho, Moscow.

Uresk, D.W., J.F. Cline, and W.H. Riekard. 1976. Impact of wildfire on 3 perennial grasses in south-central Washington. J. Range Manage. 29:309-310.

Wright, H.A., L.F. Neuenschwander, and C.M. Britton. 1979. The role and use of fire in sagebrush-grass and pinyon-juniper plant communities: A state-of-the-are review. USDA Forest Service Gen. Tech. Rep. INT-58, Int. Mtn. Forest and Range Exp. Sta., Ogden, Utah.

MOVING? Send us your new address as soon as you know it to keep journals coming to you. Our new address is SRM, 1839 York St., Denver, CO 80206. 